\title{
Kinerja Keuangan dan Return Saham Perusahaan Blue Chip di Bursa Efek Indonesia
}

\author{
Ariel Suryo ${ }^{1}$ \\ Fakultas Ekonomi dan Bisnis \\ Universitas Udayana, Indonesia
}

\author{
Gerianta Wirawan Yasa ${ }^{2}$ \\ Fakultas Ekonomi dan Bisnis \\ Universitas Udayana, Indonesia
}

\begin{abstract}
ABSTRAK
Tujuan penelitian ini untuk memberikan buktiempiris mengenai pengaruh return on asset, earning per share, dan return on equity terhadap return saham. Penelitian ini dilakukan pada perusahaan Blue Chip yang terdaftar di Bursa Efek Indonesia (BEI). Jumlah sampel yang diambil sebanyak 81 sampel, dengan metode nonprobability sampling dengan teknik sampling jenuh. Pengumpulan data dilakukan dengan observasi non-participant. Teknik analisis yang digunakan adalah teknik regresi linear berganda. Hasil analisis ditemukan bahwa return on asset, earning per share, dan return on equity berpengaruh positif terhadap return saham perusahaan Blue Chip yang terdaftar di BEI periode 2017-2019.
\end{abstract}

Surel: arilsuryo@gmail.com

Kata Kunci: Return Saham; Return On Asset; Earning Per Share; Return On Equity; Blue Chip.

\section{Financial Performance and Stock Return of Blue Chip Companies on the Indonesia Stock Exchange}

\section{ABSTRACT}

The purpose of this study is to provide empirical evidence regarding the effect of return on assets, earnings per share, and return on equity on stock returns. This research was conducted on Blue Chip companies listed on the Indonesia Stock Exchange (IDX). The number of samples taken as many as 81 samples, with non-probability sampling method with saturated sampling technique. Data collection is done by nonparticipant observation. The analysis technique used is multiple linear regression technique. The results of the analysis found that return on assets, earnings per share, and return on equity had a positive effect on stock returns of Blue Chip companies listed on the IDX for the 20172019 period.

Keywords: $\quad$ Stock Return; Return On Assets; Earnings Per Share; Return On Equity; Blue Chip.

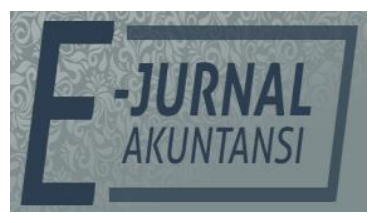

e-ISSN 2302-8556

Vol. 31 No. 12

Denpasar, Desember 2021

Hal. 3288-3300

DOI:

10.24843/EJA.2021.v31.i12.p19

PENGUTIPAN:

Suryo, A. \& Yasa, G. W.

(2021). Kinerja Keuangan dan

Return Saham Perusahaan

Blue Chip di Bursa Efek Indonesia. E-Jurnal Akuntansi,

31(12), 3288-3300

RIWAYAT ARTIKEL:

Artikel Masuk:

8 Agustus 2021

Artikel Diterima: 30 September 2021

Artikel dapat diakses: https:/ / ojs.unud.ac.id/index.php/Akuntansi/index 


\section{PENDAHULUAN}

Laporan keuangan yang dipublikasikan memiliki peranan penting yang akan menjadi pertimbangan investor dalam pengambilan keputusan investasi, untuk itu investor harus mampu menganalisis laporan keuangan. Hal yang utama dalam laporan keuangan adalah untuk menyampaikan informasi keuangan kepada khalayak mengenai kondisi kinerja keuangan perusahaan yang terbaru (Awaloedin et al., 2020). Laporan keuangan yang lengkap terdiri dari komponenkomponen berikut ini: laporan posisi keuangan pada akhir periode, laporan laba rugi komprehensif selama periode, laporan perubahan ekuitas selama periode, laporan arus kas selama periode, catatan atas laporan keuangan, berisi ringkasan kebijakan akuntansi penting dan informasi penjelasan lainnya, dan la poran posisi keuangan pada awal periode komparatif yang disajikan ketika entitas menerapkan suatu kebijakan akuntansi secara retrospektif atau membuat penyajian kembali pos-pos laporan keuangan, atau ketika entitas mereklasifikasi pos-pos dalam laporan keuangannya. Dari laporan keuangan inilah para investor akan memutuskan untuk berinvestasi atau tidaknya pada perusahaan tersebut.

Terdapat dua pendekatan yang umumnya dipakai oleh investor dalam memperkirakan harga saham di masa mendatang, yakni analisis fundamental dan analisis teknikal. Analisis fundamental menitikberatkan pada rasio finansial serta kejadian-kejadian baik secara langsung maupun tidak langsung yang mampu mempengaruhi kinerja keuangan perusahaan. Analisis fundamental berhubungan dengan penilaian kinerja perusahaan, tentang efektivitas serta efisiensi perusahaan dalam mencapai sasarannya (Almira \& Wiagustini, 2020). Analisis fundamental bertujuan untuk menentukan apakah nilai saham berada pada posisi undervalue atau overvalue (Tamuunu \& Rumokoy, 2015). Analisis fundamental merupakan salah satu cara untuk memprediksi harga saham dengan menggunakan laporan keuangan sebagai salah satu sumber informasi terutama yang terkait dengan rasio keuangan. Analisis rasio keuangan akan memberikan informasi berupa sinyal baik atau buruk mengenai kondisi keuangan perusahaan yang akan diterima oleh investor, sehingga dapat digunakan sebagai parameter kinerja keuangan perusahaan tersebut. Jikainformasi yang diperoleh investor baik dan positif maka harga saham perusahaan tersebut diperkirakan akan merefleksikan kekuatan tersebut sehingga harganya akan meningkat. Penilaian kewajaran harga saham dilakukan dengan melakukan analisis rasio-rasio fundamental perusahaan dan perbandingan nilai intrinsik dengan melakukan analisis rasio-rasio fundamental perusahaan dan perbandingan nilai intrinsik dengan harga pasar saham, sehingga hal ini dapat digunakan oleh investor untuk menggunakan rasio fundamental sebagai indikator untuk dapat memprediksi perubahan harga saham.

Rasio merupakan alat perbandingan antara jumlah satu dengan jumlah lainnya, dimana hasilnya mampu menjadi bahan pertimbangan untuk dianalisis dan diputuskan. Rasio keuangan berperan penting dalam penilaian sebuah perusahaan, karena dengan menggunakan rasio, investor mampu menilai kinerja keuangan suatu perusahaan. Terdapat lima jenis analisis rasio yang paling sering digunakan, yaitu: rasio profitabilitas, rasio pasar, rasio likuiditas, rasio solvabilitas, dan rasio aktivitas. Rasio likuiditas adalah rasio yang digunakan untuk mengetahui kemungkinan kemampuan perusahaan dalam memenuhi 
kewajiban keuangan jangka pendeknya yang harus dipenuhi. Rasio aktivitas merupakan rasio yang mengukur kemampuan aktiva perusahaan dalam menghasilkan pendapatan. Rasio solvabilitas memiliki kemiripan dengan rasio likuiditas, yang membedakannya adalah rasio solvabilitas mengukur kemampuan perusahaan dalam memenuhi kewajiban jangka panjangnya. Rasio profitabilitas adalah rasio yang digunakan untuk menilai kemampuan perusahaan dalam mencari keuntungan pada suatu periode tertentu. Menurut Yanti \& Afriyeni (2017) untuk melihat kemampuan perusahaan dalam memperoleh laba pada periode tertentu maka digunakan rasio profitabilitas seperti return on asset dan return on equity. Profitabilitas pada suatu perusahaan dapat dikatakan baik apabila perusahaan mampu memenuhi target laba yang telah ditetapkan berdasarkan aktiva atau modal yang ada pada periode tersebut, karena apabila pengelolaan keuangannya tidak baik maka akan mengakibatkan terganggunya kinerja perusahaan. Dengan rasio profitabilitas, perbandingan dari sebuah perusahaan dengan perusahaan serupa dapat dinilai dengan lebih baik, sehingga investor dapat melakukan perbandingan dan menilai apakah perusahaan tersebut baik atau tidak. Penggunaan rasio profitablitias dapat dilakukan dengan menggunakan perbandingan antara komponen yang ada pada laporan keuangan terutama pada neraca dan laporan laba rugi (Vernida \& Marlius, 2019). Rasio profitabilitas yang digunakan dalam penelitian ini yaitu return on asset yang berfungsi untuk mengukur efektivitas perusahaan dalam menghasilkan laba dengan memanfaatkan aktiva yang dimilikinya dan return on equity yang menggambarkan kemampuan perusahaan dalam menghasilkan laba menggunakan modal yang dimiliki perusahaan itu sendiri. Laba yang tinggi akan menarik minat investor dalam berinvestasi karena perusahaan tersebut berarti mengalami peningkatan pengembalian yang tinggi. Rasio terakhir adalah rasio pasar yang berfungsi untuk mengukur harga pasar relatif terhadap nilai buku. Sudut pandang rasio ini lebih banyak berdasar pada sudut investor atau calon investor meskipun pihak internal perusahaan juga berkepentingan terhadap rasio-rasio ini. Rasio pasar dapat juga digunakan sebagai indikator untuk mengukur mahal atau murahnya suatu saham yang dapat membantu investor dalam mencari saham yang memiliki potensi keuntungan dividen yang besar sebelum mengambil keputusan investasi. Rasio pasar merupakan sekumpulan rasio yang menghubungkan harga saham dengan laba, nilai buku per saham, dan dividen yang hasilnya bisa memberikan petunjuk mengenai apa yang dipikirkan investor atas kinerja perusahaan di masa lalu serta prospek di masa mendatang (Moeljadi, 2006:75). Rasio pasar yang digunakan dalam penelitian ini yaitu earning per share yang menunjukkan besarnya laba bersih per lembar saham yang akan dibagikan kepada setiap pemegang saham perusahaan. Jika EPS semakin tinggi, investor akan tertarik dan membeli saham tersebut sehingga menyebabkan harga saham akan semakin tinggi.

Teori yang mendasari penelitian ini adalah teori sinyal yang menyatakan bahwa pihak internal seperti manajemen yang berperan sebagai pihak yang memberikan sinyal dan investor sebagai pihak eksternal yang menerima sinyal tersebut. Dalam memberikan sinyal, pihak manajemen berusaha memberikan informasi yang relevan sehingga dapat dimanfaatkan oleh investor, kemudian investor akan menyesuaikan keputusan yang diambilnya sesuai dengan pemahamannya terhadap sinyal tersebut. Teori sinyal menekankan kepada 
informasi yang dikeluarkan perusahaan terhadap keputusan investasi di pihak luar perusahaan (Abdul \& Awan, 2014). Saat informasi sudah diterima oleh para investor, investor akan menganalisis dan menginterpretasikan informasi tersebut sebagi sinyal baik atau buruk. Teori ini mengasumsikan pihak internal perusahaan memiliki informasi yang lebih baik mengenai perusahaan yang tidak diketahui oleh pihak eksternal perusahaan, dan internal perusahaan (manajer) merupakan pihak yang selalu memaksimalkan insentif yang diharapkannya.

Return saham adalah keuntungan yang diperoleh oleh perusahaan, institusi, dan individu dari hasil kebijakan investasi yang dilakukannya. Dalam dunia investasi dikenal adanya hubungan kuat antara risk dan return, yang artinya semakin tinggi risiko, akan semakin tinggi pula return yang akan kita dapat, begitu pula sebaliknya (Handayani \& Zulyanti, 2018). Investor akan lebih tertarik untuk membeli saham yang memiliki return yang tinggi. Oleh sebab itu, investor dan investor potensial akan memprediksi seberapa besar pengembalian yang akan diperoleh dari saham yang dibelinya (Mirayanti \& Wirama, 2017). Terdapat banyak faktor yang mempengaruhi return saham, salah satunya ROA. Penelitian dari Putra \& Kindangen (2016), Mayuni \& Suarjaya (2018), Khalil et al. (2016), Maringka et al. (2016) dan Hasan et al. (2020) yang memperoleh hasil bahwa ROA berpengaruh posistif signifikan terhadap return saham. EPS juga menjadi salah satu faktor yang mempengaruhi return saham, seperti penelitian yang dilakukan oleh Selviani \& Prima (2020), Mayuni \& Suarjaya (2018), Handayani \& Zulyanti (2018) dan Agrawal \& Bansal (2020) menyatakan bhwa terdapat hubungan yang positif antara EPS dengan return saham. Faktor selanjutnya yang mempengaruhi return saham tahunan adalah $\mathrm{ROE}$, seperti penelitian yang dilakukan oleh Tumonggor et al. (2017), Nasiri et al. (2016), Aryanti et al. (2016), Nalurita (2015), dan Latifah \& Pratiwi (2019) menemukan bahwa ROE berpengaruh positif terhadap return saham.

Penelitian ini relatif berbeda dengan penelitian terdahulu karena sampel yang digunakan adalah perusahaan-perusahaan Blue Chip yang terdaftar dalam BEI selama periode 2017-2019. Sampel yang digunakan adalah perusahaan Blue Chip, karena peneliti melihat pertumbuhan investor di Indonesia yang cukup signifikan, peneliti berharap agar investor dan calon investor tidak salah dalam pengambilan keputusan investasi. Menurut New York Stock Exhange, Blue Chip merupakan saham dari perusahaan yang memiliki reputasi nasional baik dari sisi kualitas, kemampuan serta kehandalan untuk beroperasi yang menguntungkan dalam berbagai situasi ekonomi dengan keadaan baik maupun buruk. Saham perusahaan Blue Chip atau big cap dapat diartikan sebagai saham papan atas atau saham unggulan dengan kapitalisasi pasar diatas 20 triliun rupiah, semakin tinggi nilai kapitalisasi pasar suatu perusahaan, semakin menunjukkan jika perusahaan tersebut adalah perusahaan yang besar dan mapan, karena kapitalisasi pasar suatu perusahaan menunjukkan nilai dari harga keseluruhan perusahaan tersebut. Saham perusahaan Blue Chip juga memiliki nilai saham yang stabil dan resikonya cenderung lebih kecil dibandingkan dengan saham second liner maupun third liner. Perusahaan dengan kategori Blue Chip secara umum adalah perusahaan yang besar, perusahaan dengan etos kerja yang baik, perusahaan dengan fundamental yang baik, dan dikelola oleh para professional. Perusahaan Blue Chip biasanya bergerak di bidang industri dan keuangan yang hasilnya banyak dibutuhkan oleh 
masyarakat, sehingga dapat dipastikan jika perusahaan Blue Chip memiliki keuntungan yang besar dan rutin dibagikan kepada para pemegang sahamnya

Nilai ROA yang tinggi dapat memberikan gambaran informasi bahwa kemampuan perusahaan dalam menghasilkan laba juga baik, hal ini akan menarik minat investor untuk membeli saham dan menanamkan dananya sehingga akan berdampak pada meningkatnya return saham yang akan dinikmati oleh pemegang saham. Teori tersebut didukung oleh penelitian yang dilakukan oleh Putra \& Kindangen (2016), Mayuni \& Suarjaya (2018), Khalil et al. (2016), Maringka et al. (2016) dan Hasan et al. (2020) yang menyimpulkan bahwa ROA berpengaruh posistif terhadap return saham. Semakin tinggi ROA, semakin baik pula kinerja perusahaan dalam mengelola aset yang dimikili untuk memperoleh laba, sehingga investor akan lebih tertarik untuk berinvestasi pada perusahaan tersebut, hal ini sesuai dengan teori sinyal dimana pihak manajemen mampu memberikan sinyal baik kepada investor mengenai prospek yang baik dari perusahaan tersebut. Berdasarkan uraian tersebut maka dikembangkan hipotesis:

$\mathrm{H}_{1}$ : Retrun on Asset berpengaruh positif terhadap return saham.

Berdasarkan teori sinyal, salah satu informasi yang perlu diketahui oleh investor adalah besarnya laba suatu perusahaan. Semakin tinggi EPS berarti semakin tinggi tingkat keuntungan per lembar saham yang dimiliki investor (Stefano, 2015). Hal ini dikuatkan dengan bukti empiris yang dilakukan oleh Selviani \& Prima (2020), Mayuni \& Suarjaya (2018), Handayani \& Zulyanti (2018) dan Agrawal \& Bansal (2020) menyatakan bahwa EPS berpengaruh positif terhadap return saham. EPS yang tinggi menunjukkan perusahaan tersebut memiliki laba yang tinggi pula, sehingga EPS mampu dijadikan bahan pertimbangan para investor dalam pengambilan keputusan investasi. Hal ini sesuai dengan teori sinyal, dimana pihak manajemen memberikan petunjuk kepada investor dengan menyampaikan kabar baik mengenai perusahaan tersebut. Berdasarkan uraian tersebut maka dikembangkan hipotesis:

$\mathrm{H}_{2}$ : Earning per Share berpengaruh positif terhadap return saham.

Menurut penelitian yang dilakukan oleh Tumonggor et al. (2017) \& Nasiri et al. (2016) hasil penelitiannya menunjukkan bahwa ROE berpengaruh positif terhadap return saham. Hasil penelitian yang serupa dilakukan oleh Aryanti et al. (2016) \& Nalurita (2015), menemukan bahwa ROE memiliki pengaruh yang positif terhadap return saham. Hasil penelitian Latifah \& Pratiwi (2019) juga menemukan bahwa ROE berpengaruh positif terhadap return saham. Hal ini berarti semakin tinggi ROE suatu perusahaan, maka semakin tinggi pula return saham yang dihasilkan. Perusahaan yang memiliki tingkat ROE yang tinggi menunjukkan kemampuan perusahaan dalam memperoleh laba dengan modal sendiri yang dimilikinya, sehingga semakin tinggi ROE suatu perusahaan, semakin baik pula kinerja perusahaan tersebut dalam menghasilkan laba. ROE yang tinggi akan ditangkap sebagai sinyal baik bagi investor, sehingga mampu dijadikan bahan pertimbangan dalam mengambil keputusan investasi.

$\mathrm{H}_{3}$ : Return on Equity berpengaruh positif terhadap return saham. 


\section{METODE PENELITIAN}

Lokasi penelitian ini dilakukan pada perusahaan Blue Chip yang terdaftar di Bursa Efek Indonesia pada tahun 2017-2019 yang diakses di situs resmi Bursa Efek Indonesia (www.idx.co.id) dan situs resmi perusahaan.

Populasi dalam penelitian ini adalah perusahaan Blue Chip yang terdaftar di Bursa Efek Indonesia. Metode penentuan sampel pada penelitian ini menggunakan non probability sampling dengan teknik sampling jenuh (sensus) yaitu metode penentuan sampel bila semua anggota populasi dijadikan sebagai sampel, maka sampel yang dijadikan objek dalam penelitian ini perusahaan Blue Chip yang terdaftar di Bursa Efek Indonesia periode 2017-2019 sebanyak 27 perusahaan.

Analisis regresi linear berganda (multiple linear regression) digunakan untuk menguji hipotesis yang ada yaitu untuk melihat pengaruh return on asset, earning per share, dan return on equity terhadap retrurn saham. Analisis linear berganda digunakan untuk memecahkan rumusan masalah yang ada, yaitu untuk melihat pengaruh dua variabel atau lebih. Model persamaan analisis regresi linear berganda ditunjukkan oleh persamaan regresi berikut.

Keterangan:

$$
\mathrm{RS}=\alpha+\beta_{1} \mathrm{ROA}+\beta_{2} \mathrm{EPS}+\beta_{3} \mathrm{ROE}+\varepsilon
$$

$$
\begin{array}{ll}
\mathrm{RS} & =\text { Return saham } \\
\mathrm{ROA} & =\text { Return on Asset } \\
\mathrm{EPS} & =\text { Earning per Share } \\
\mathrm{ROE} & =\text { Return on Equity } \\
\mathrm{a} & =\text { Konstanta } \\
\beta & =\text { Koefisien Regresi } \\
\mathcal{E} & =\text { error atau variabel pengganggu }
\end{array}
$$

\section{HASIL DAN PEMBAHASAN}

Statistik deskriptif digunakan untuk memberikan gambaran dari suatu data yang dilihat dari jumlah sampel, nilai minimum, nilai maksimum, nilai rata-rata, dan devisiasi standar dari masing-masing variabel dalam penelitian. Hasil dari statistik deskriptif dapat dilihat pada Tabel 1 sebagai berikut.

\section{Tabel 1. Hasil Analisis Statistik Deskriptif}

\begin{tabular}{llllll}
\hline Variabel & $\mathrm{N}$ & Minimum & Maksimum & Rata-rata & Deviasi Standar \\
\hline Return saham & 81 & $-0,616$ & 2,160 & 0,075 & 0,364 \\
ROA & 81 & $-6,000$ & 60,600 & 9,365 & 10,817 \\
EPS & 81 & $-308,000$ & 5.655 & 652,367 & $1.000,865$ \\
ROE & 81 & $-18,000$ & 191,600 & 21,871 & 33,576 \\
Valid N (listwise) & 81 & & & &
\end{tabular}

\section{Sumber: Data Penelitian, 2021}

Berdasarkan hasil uji statistik deskriptif pada Tabel 1 menunjukkan jumlah $\mathrm{N}$ sebanyak 81 . Hal ini berarti terdapat 81 data observasi yang diteliti yaitu terdiri dari 27 perusahaan selama 3 tahun periode penelitian yaitu dari 2017-2019 yang dideskripsikan yaitu return saham memiliki nilai minimum sebesar $-0,616$ pada PT. Bukit Asam Tbk. tahun 2018, sehingga mengindikasikan perusahaan tersebut memiliki return saham paling rendah dibandingkan dengan sampel perusahaan lainnya dan nilai maksimum sebesar 2,160 pada PT. Barito Pacific Tbk. tahun 2019 yang berarti perusahaan ini memiliki tingkat return saham paling tinggi 
dibandingkan dengan return sampel perusahaan lainnya, serta rata-rata tingkat return saham sebesar 0,075, yang berarti rata-rata perusahaan yang menjadi sampel memiliki return yang rendah. Nilai deviasi standar sebesar 0,364 lebih tinggi dibandingkan nilai rata-rata yang memiliki arti bahwa data return saham yang bervariasi atau terdapat besarnya perbedaan antara data satu dengan yang lainnya atau rentang persebaran data return saham.

Tabel 1 menunjukkan return on asset memiliki nilai rata-rata 9,365 yang berarti sebagian besar perusahaan yang menjadi sampel memiliki kemampuan menghasilkan laba menggunakan aset yang dimiliki perusahaan yang rendah, dengan nilai minimum sebesar -6 pada PT. XL Axiata Tbk. tahun 2018 yang artinya perusahaan ini memiliki nilai ROA yang paling rendah dibandingkan dengan sampel perusahaan lainnya dan nilai maksimum 60,600 pada PT Unilever Indonesia Tbk. tahun 2018 sebagai perusahaan dengan nilai ROA tertinggi dibandingkan dengan sampel perusahaan lainnya. Deviasi standar sebesar 10,817, lebih tinggi dibandingkan dengan nilai rata-rata yang menunjukkan bahwa tingkat variasi data terkait ROA yang tinggi, atau terdapat perbedaan yang cukup tinggi pada data satu dengan yang lainnya.

Earning per Share pada Tabel 1 memiliki nilai rata-rata sebesar 652,367, sehingga disimpulkan bahwa sebagian besar sampel perusahaan memiliki laba per lembar saham yang rendah dengan nilai minimum -308 pada PT. XL Axiata Tbk. tahun 2018 yang artinya perusahaan ini memiliki tingkat laba per lembar saham paling kecil dibandingkan sampel perusahaan lainnya, dan nilai maksimum 5.655,000 pada PT. Gudang Garam Tbk. tahun 2019, sehingga perusahaan ini memiliki laba per lembar saham tertinggi dibandingkan dengan perusahaan lainnya yang menjadi sampel dalam penelitian ini. Nilai rata-rata cenderung mendekati nilai minimum yang berarti sebagian besar tingkat laba per lembar saham perusahaan yang menjadi sampel rendah. Nilai deviasi standar sebesar 1.000,865 lebih tinggi dibandingkan dengan nilai rata-rata yang menunjukkan bahwa tingkat variasi data terkait EPS yang tinggi, atau terdapat perbedaan yang cukup tinggi pada data satu dengan yang lainnya.

Return on Equity memiliki nilai rata-rata sebesar 21,871 yang berarti sebagian besar perusahaan yang menjadi sampel dalam penelitian ini memiliki kemampuan menghasilkan laba dengan modal sendiri yang rendah. Nilai minimum -18,000 pada perusahaan PT. XL Axiata Tbk. tahun 2018 yang berarti perusahaan ini memiliki kemampuan menghasilkan laba menggunakan modal sendiri paling rendah dibanding sampel perusahaan lain dalam penelitian ini, dan nilai maksimum 191,600 pada perusahaan PT. Unilever Indonesia Tbk. tahun 2019 yang artinya perusahaan ini memiliki kemampuan menghasilkan laba yang baik dan paling tinggi menggunakan modal sendiri dibanding perusahaan lain yang menjadi sampel dalam penelitian ini. Nilai deviasi standar sebesar 33,576 lebih tinggi dibandingkan dengan nilai rata-rata yang menunjukkan bahwa tingkat variasi data terkait ROE yang tinggi, atau terdapat perbedaan yang cukup tinggi pada data satu dengan yang lainnya.

Analisis regresi linier berganda ini digunakan untuk menganalisis pengaruh return on asset, earning per share, dan return on equity terhadap retum saham perusahaan Blue Chip yang terdaftar di BEI periode 2017-2019. Analisis 
regresi linear berganda diolah dengan bantuan software SPSS for Windows 22.0 dengan hasil yang dapat dilihat pada Tabel 2 sebagai berikut:

Tabel 2. Hasil Uji Analisis Regresi Linear Berganda

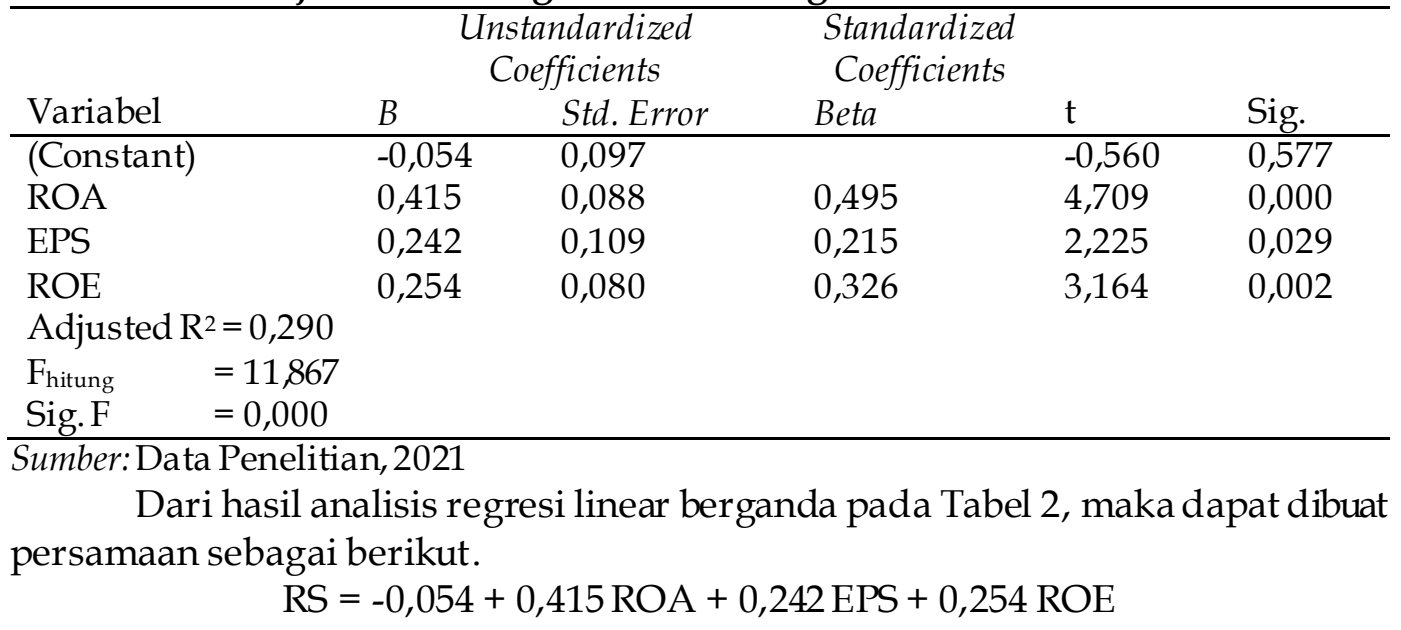

Berdasarkan hasil pengujian pada tabel 2 menunjukkan bahwa ROA dengan tingkat signifikansi sebesar 0,000 nilai ini lebih kecil dari 0,05, sehingga dapat disimpulkan bahwa ROA berpengaruh positif terhadap return saham dan sejalan dengan hipotesis penelitian sehingga $\mathrm{H}_{1}$ diterima. Hal ini memiliki arti bahwa semakin tinggi ROA maka semakin tinggi juga return saham suatu perusahaan. Penelitian ini sejalan dengan penelitian yang dilakukan oleh (Putra \& Kindangen, 2016), (Mayuni \& Suarjaya, 2018), (Khalil et al., 2016), (Maringka et al., 2016), dan (Hasan et al., 2020) yang menyatakan dalam penelitiannya bahwa ROA berpengaruh positif terhadap return saham.

Hal ini juga sejalan dengan teori sinyal, dimanainformasi mengenai kinerja keuangan, dalam hal ini ROA merupakan informasi yang penting untuk diketahui oleh pihak yang berkepentingan seperti investor maupun calon investor. Peningkatan maupun penurunan nilai ROA akan memberikan sinyal bagi investor sehingga investor maupun calon investor mampu menjadikan ROA sebagai bahan pertimbangan dalam mengambil keputusan investasi saham perusahaan Blue Chip. Berdasarkan hasil pengujian pada tabel 2 menunjukkan bahwa EPS dengan tingkat signifikansi sebesar 0,029 nilai ini lebih kecil dari 0,05, sehingga dapat disimpulkan bahwa EPS berpengaruh positif terhadap return saham dan sejalan dengan hipotesis penelitian sehingga $\mathrm{H}_{2}$ diterima. Hasil tersebut memiliki arti bahwa pada perusahaan Blue Chip yang mengalami peningkatan EPS akan memicu peningkatan return saham ke arah yang positif, begitu pula sebaliknya.

Hal ini mendukung teori sinyal karena perkembangan yang terjadi di suatu perusahaan dapat menjadi sinyal yang baik bagi para investor dan calon investor akan prospek perusahaan di masa yang akan datang. Pandangan yang baik dari investor mengenai prospek suatu perusahaan akan berpengaruh pada naiknya harga saham yang juga berdampak pada nilai return saham perusahaan tersebut. Hasil penelitian ini sejalan dengan penelitian sebelumnya yang dilakukan oleh (Selviani \& Prima, 2020), (Mayuni \& Suarjaya, 2018), (Handayani \& Zulyanti, 2018), dan (Agrawal \& Bansal, 2020) yang menyatakan dalam penelitiannya bahwa EPS berpengaruh positif terhadap return saham. 
Berdasarkan hasil pengujian pada Tabel 2 menunjukkan bahwa EPS dengan tingkat signifikansi sebesar 0,002 nilai ini lebih kecil dari 0,05, sehingga dapat disimpulkan bahwa ROE berpengaruh positif terhadap return saham dan sejalan dengan hipotesis penelitian sehingga $\mathrm{H}_{3}$ diterima. Hal ini berarti bahwa semakin tinggi ROE maka semakin tinggi juga return saham suatu perusahaan. Penelitian ini sejalan dengan penelitian yang dilakukan oleh (Tumonggor et al., 2017), (Nasiri et al., 2016), (Aryanti et al., 2016), (Nalurita, 2015), dan (Latifah \& Pratiwi, 2019) yang menyatakan dalam penelitiannya bahwa ROE berpengaruh positif terhadap return saham.

Hal ini juga sesuai dengan teori sinyal, dimana informasi mengenai kinerja keuangan, seperti ROE merupakan informasi yang penting untuk diketahui oleh pihak yang berkepentingan seperti investor maupun calon investor. Baik peningkatan maupun penurunan nilai ROE akan memberikan sinyal bagi investor sehingga investor maupun calon investor mampu menjadikan ROE sebagai bahan pertimbangan dalam mengambil keputusan investasi saham perusahaan Blue Chip.

Koefisien determinasi $\left(\mathrm{R}^{2}\right)$ digunakan untuk mengetahui dan mengukur kemampuan model dalam menerangkan variasi variabel independen. Hasil uji pada Tabel 2 memberikan hasil dimana diperoleh besarnya nilai Adjusted $\mathrm{R}^{2}$ adalah sebesar 0,290. Ini berarti sebesar 29 persen variasi return saham perusahaan Blue Chip yang terdaftar di Bursa Efek Indonesia periode 2017-2019 dapat dipengaruhi secara signifikan oleh variabel return on asset, earning per share, dan return on equity sedangkan sisanya sebesar 71 persen dijelaskan oleh faktor-faktor lain. Hasil uji $\mathrm{F}$ menunjukkan bahwa nilai $\mathrm{F}$ hitung sebesar 11,867 dengan nilai signifikansi 0,000 yang lebih kecil dari $\alpha=0,05$, ini berarti model yang digunakan pada penelitian ini adalah layak. Hasil ini memberikan makna bahwa ketiga variabel independen mampu memprediksi atau menjelaskan fenomena return saham. Hal ini berarti secara simultan return on asset, earning per share, dan return on equity berpengaruh signifikan terhadap return Saham.

Penelitian ini mendukung adanya teori sinyal tentang tindakan perusahaan dalam memberikan sinyal kepada pihak-pihak yang berkepentingan seperti investor maupun calon investor tentang bagaimana manajemen memandang suatu perusahaan. Sinyal-sinyal yang diberikan perusahaan atau manajemen berupa informasi keuangan maupun non keuangan dapat dijadikan bahan pertimbangan sebagai dasar pertimbangan pengambilan keputusan investasi. Hasil uji dalam penelitian ini menunjukkan bahwa informasi keuangan berupa return on asset, earning per share, dan return on equity memberikan sinyal positif yang dapat mempengaruhi return saham perusahaan Blue Chip. Peningkatan ROA dalam perusahaan dapat menjadi sinyal posifit bagi pihak investor maupun calon investor karena mengandung informasi terkait bagaimana tingkat kemampuan perusahaan menghasilkan laba menggunakan asset yang dimiliki. Peningkatan EPS dapat menjadi sinyal positif dengan memberikan gambaran terkait seberapa besar laba per lembar saham suatu perusahaan. ROE yang mengalami peningkatan juga dapat memberikan sinyal positif dengan menunjukkan tingkat kemampuan perusahaan menghasilkan laba menggunakan modal yang dimiliki perusahaan itu sendiri. 
Penelitian ini memberikan implikasi praktis bagi pihak yang berkepentingan berdasarkan hasil uji penelitian ini yang diharapkan membantu pemegang saham khususnya perusahaan Blue Chip maupun calon investor yang akan mulai berinvestasi di pasar modal dalam menilai kinerja perusahaan melalui informasi keuangan seperti return on asset, earning per share, dan return on equity. Selain itu dengan adanya hasil uji penelitian ini, diharapkan bagi pihak manajemen maupun perusahaan untuk dapat lebih memperhatikan informasi keuangan yang dimiliki, sehingga dapat memberikan sinyal dalam bentuk informasi keuangan dengan baik dan benar. Hasil penelitian ini juga diharapkan dapat menjadi tambahan literatur berkaitan dengan pasar modal, sehingga dapat bermanfaat bagi penelitian selanjutnya.

\section{SIMPULAN}

Return on Asset berpengaruh positif terhadap return saham. Hal ini berarti semakin tinggi kemampuan perusahaan menghasilkan laba menggunakan aset yang dimiliki, semakin tinggi pula return saham perusahaan Blue Chip tahun 2017-2019. Earning per Share berpengaruh positif terhadap return saham. Hal ini berarti semakin tinggi jumlah laba per lembar saham, semakin tinggi pula return saham perusahaan Blue Chip tahun 2017-2019. Return on Equity berpengaruh positif terhadap return saham. Hal ini berarti semakin tinggi kemampuan perusahaan menghasilkan laba menggunakan modal yang dimiliki perusahaan itu sendiri, semakin tinggi pula return saham perusahaan Blue Chip tahun 2017-2019.

Bagi investor, sebelum membeli saham diharapkan dapat melakukan analisis perusahaan secara menyeluruh agar mampu menghasilkan return yang memadai di masa mendatang, salah satunya dengan menggunakan informasi keuangan yang disajikan perusahaan seperti return on asset, earning per share, dan return on equity dalam menjadikan dasar pengambilan keputusan investasi.

Bagi peneliti selanjutnya, diharapkan dapat lebih menyempurnakan penelitian ini dengan menggunakan rasio keuangan lainnya agar dapat mengetahui faktor lain yang mempengaruhi return saham serta memperpanjang periode penelitian agar hasil yang diperoleh lebih representatif, menggunakan objek penelitian yang berbeda seperti indeks saham maupun sektor perusahaan lain yang menarik untuk investor menanamkan modalnya dalam pasar modal. Peneliti selanjutnya juga sebaiknya mengkategorikan penelitian berdasarkan tipe industri atau ukuran perusahaan agar sampel penelitian yang digunakan lebih fokus ke golongan tertentu.

\section{REFERENSI}

Agrawal, O. P., \& Bansal, P. K. (2020). Materials Today: Proceedings A critical study on relationship of EPS and stock price. Materials Today: Proceedings, 1-5. https:/ / doi.org/10.1016/j.matpr.2020.08.722

Almira, N. P. A. K., \& Wiagustini, N. L. P. (2020). Return on Asset, Return on Equity, dan Earning per Share Berpengaruh Terhadap Return Saham. EJurnal Manajemen, 9(3), 1069-1088.

Anwaar, M. (2016). Impact of Firms' PerformanceonStock Returns (Evidence from Listed Companies of Ftse-100 Index London, UK). Global Journal of Management and Business Research, 16(1), 31-39. 
Arikunto. 2013. Prosedur Penelitian Suatu Pendekatan Praktis. Jakarta: Bina Aksara.

Aryanti, Mawardi, \& Andesta, S. (2016). Pengaruh ROA, ROE, NPM Dan CR Terhadap Return Saham Pada Perusahaan Yang Terdaftar Di Jakarta Islamic Index (JII). I-Finance, 2(2), 54-71.

Assagaf, A., Murwaningsari, E., Gunawan, J., \& Mayangsari, S. (2019). The Effect of Macro Economic Variables on Stock Return of Companies That Listed in Stock Exchange: Empirical Evidence from Indonesia. International Journal of Business and Management, 14(8), 108-116. https:// doi.org/10.5539/ijbm.v14n8p108

Awaloedin, D. T., Hasanudin, \& Subekti, S. W. M. (2020). Tinjauan Analisis Kinerja Laporan Keuangan Pada Perusahaan Food \& Beverage Yang Terdaftar di BEI Pada Tahun 2013-2017. Jurnal Rekayasa Akuntansi, 9(1), 26-43.

Bagaskoro, B. S., A, A. F., \& Widagdo, A. K. (2019). The Effect Of Stock Split On Liquidity Stock In Companies Which Listed On BEI 2007-2015. International Journal of Economics, Business and Management Research, 3(11), 160-169.

Brigham, \& Houston. (2014). Dasar-Dasar Manajemen Keuangan (11th ed.). Jakarta: Salemba Empat.

Fahmi, M. M., \& Sulhan, M. (2020). Pengaruh Free Cash FLow dan Investment Opportunity Set Terhadap Kebijakan Deviden dengan Kepemilikan Institusional Sebagai Variabel Pemoderasi. Jurnal Ilmiah Manajemen, 8(2), 43-63.

Ghozali, H. Imam. 2016. Aplikasi Analisis Multivariate dengan Program IBMSPSS 23. Edisi Kedelapan. Semarang: Badan Penerbit Universitas Diponegoro.

Handayani, R., \& Zulyanti, N. R. (2018). Pengaruh Earning Per Share (EPS), Debt To Equity Ratio, (DER), Dan Return on Assets (ROA) Terhadap Return Saham Pada Perusahaan Manufaktur Yang Terdaftar Di Bei. Jurnal Manajemen, 3(1), 615-620. https:// doi.org/10.30736/jpim.v3i1.143

Hasan, I., Mas'ud, M., \& Serang, S. (2020). Pengaruh Return on Asset, Debt to Equity Ratio dan Return on Equity terhadap Return Saham pada Perusahaan Makanan dan Minuman yang Terdaftar di Bursa Efek Indonesia Tahun 2015-2018. Paradoks, 3(3), 19-30.

Hati, I. P., \& Rosini, I. (2017). Pengaruh Opini Audit Tahun Sebelumnya dan Kondisi Keuangan terhadap Opini Audit Going Concern. 2(2), 123-133.

Hendarsih, I., \& Harjunawati, S. (2020). Penggolongan Saham perusahaan Blue Chip Berdasarkan Kapitalisasi Pasar Pada Bursa Efek Indonesia Tahun 2017-2020. Psychology Applied to Work: An Introduction to Industrial and Organizational Psychology, Tenth Edition Paul, 5(2), 115-133.

Khalil, M., Ullah, S., \& Ali, S. (2016). Arabian Journal of Business and The Effect of Corporate Cash Holdings on Stock Returns. Arabian Journal of Business and Management Review, 6(6), 1-9. https:// doi.org/10.4172/2223-5833.1000262

Latifah, W. R., \& Pratiwi, P. D. (2019). Analisis Pengaruh Current Ratio, Debt to Equity Ratio, dan Return on Equity Terhadap Return Saham Pada Perusahaan Real Estate dan Property yang Terdaftar di Bursa Efek Indonesia Periode 2014-2017. JURNAL FOKUS, 2(1), 255-269. 
Laurens, S. (2018). Influence Analysis of DPS, EPS, and PBV toward Stock Price and Return. The Winners, 19(1), 21-29. https:// doi.org/10.21512/tw.v19i1.4496

Maringka, T. S., Moeljadi, P., Djazuli, A., \& Ratnawati, K. (2016). Leverage , Free Cash Flow, and Interest Rates Influence of Stock Return and Financial Performance as Intervening Variables ( Study on Manufacturing Industry Listed in Indonesia Stock Exchange ). International Journal of Business and Management Invention, 5(2), 28-30.

Martina, S., Sadalia, I., \& Bukit, R. (2019). TheEffect Of Quick Ratio, Debt To Equity Ratio, Earning Per Share, Price To Book Value And Return On Equity On Stock Return With Money Supply As Moderated Variables (Study of Banking Companies Listed on Indonesia Stock Exchange Period 2008 2017). International Journal of Public Budgeting, Accounting and Finance, 2(3), $1-10$.

Mayuni, I. A. I., \& Suarjaya, G. (2018). Pengaruh ROA, Firm Size, EPS, Dan PER Terhadap Return Saham Pada Sektor Manufaktur Di Bei. E-Jurnal Manajemen Universitas Udayana, 7(8), 4063-4093. https:/ / doi.org/10.24843/EJMUNUD.2018.v07.i08.p02

Mirayanti, N. M., \& Wirama, D. G. (2017). Pengaruh Variabel Ekonomi Makro Pada Return Saham LQ45 di Bursa Efek Indonesia. E-Jurnal Akuntansi Universitas Udayana, 21(1), 505-533.

Mulyana, M., Hidayat, L., \& Puspitasari, R. (2019). Mengukur Pengetahuan Investasi Para Mahasiswa Untuk Pengembangan Galeri Investasi Perguruan Tinggi. Jurnal Analisis Sistem Pendidikan Tinggi, 3(1),31-52.

Mwaurah, I., Muturi, W., \& Waititu, A. (2017). The Influence of Credit Risk on Stock Returns. International Journal of Scientific and Research Publications, 7(5), 575-584.

Nalurita, F. (2015). The Effect of Profitability Ratio, Solvability Ratio, Market Ratio The Effect Of Profitability Ratio, Solvability Ratio , Market Ratio On Stock Return. Business and Entrepreneurial Review, 15(1), 73-94. https:/ / doi.org/10.25105/ber.v15i1.2080

Nasiri, M. M., Mir, M., \& Samani, A. R. (2016). The effect of Shareholders' Combination on Risk Taking of the Companies Listed in Tehran Stock Exchange. International Journal of Business Continuity and Risk Management, 6(3), 1-12. https://doi.org/10.1504/ IJBCRM.2016.079009

Nugroho, Y. B. (2020). The Effect of Book to Market Ratio, Profitability, and Investment on Stock Return. International Journal of Economics and Management Studies, $\quad 7(6), \quad 102-107$. https:/ / doi.org/10.14445/23939125/ijems-v7i6p114

Putra, F. E., \& Kindangen, P. (2016). Pengaruh Return on Asset (Roa), Net Profit Margin (Npm), Dan Earning Per Share (Eps) Terhadap Return Saham Perusahaan Makanan Dan Minuman Yang Terdaftar Di Bursa Efek Indonesia (Periode 2010-2014). Jurnal Riset Ekonomi, Manajemen, Bisnis Dan Akuntansi, 4(4), 235-245.

Samsul, Mohammad. (2006). Pasar Modal dan Manajemen Portofolio. Surabaya: Erlangga. 
Scott, William R. 2012. Financial Accounting Theory. Sixth Edition Canada: Pearson Prentice Hall.

Selviani, N., \& Prima, A. P. (2020). Pengaruh Return on Assets, Net Profit Margin Dan Earning Per Share Terhadap Return Saham Perusahaan Yang Terdaftar Di Bursa Efek. EDUTECH CONSULTANT BANDUNG Jurnal AKSARA PUBLIC, 4(9), 11-21.

Stefano, K. (2015). The Impact of Financial Ratio toward Stock Return of Property Industry in Indonesia. IBuss Management, 3(2), 222-231.

Sugiyanto. (2000). Keterbatasan Uji Signifikansi: Ilustrasi Pada Analisis Korelasi 2 Variabel. ISSN : 0854 - 7108 Buletin Psikologi, Tahun VIII, No. 2 Desember 2000

Sugiyono. 2017. Metode Penelitian dan Bisnis. Bandung: Alfabeta.

Tamuunu, S. C., \& Rumokoy, F. (2015). The Influence of Fundamental Factors on Stock Return (Case Study: Company Listed in Lq452011-2014). Jurnal Riset Ekonomi, Manajemen, Bisnis Dan Akuntansi, 3(4), 628-636.

Tumonggor, M., Murni, S., \& Rate, P. Van. (2017). Analisis Pengaruh Current Ratio, Return on Equity, Debt To Equity Ratio Dan Growth Terhadap Return Saham Pada Cosmetics and Household Industry Yang Terdaftar Di Bei Periode 2010-2016. Jurnal EMBA:Jurnal Riset Ekonomi, Manajemen, Bisnis Dan Akuntansi, 5(2), 2203-2210.

Vernida, M., \& Marlius, D. (2019). Analisis Rasio Profitabilitas Pada Pt. Bank Perkreditan Rakyat Cempaka Mitra Nagari Padang. 1-11. https:/ / doi.org/10.31219/osf.io/d3qrp.

Widiastuti, D. A., \& Asteria, B. (2019). FaktorDeterminan Kemampulabaan Saham perusahaan Blue Chip Di Bursa Efek Indonesia. Kajian Bisnis STIE Widya Wiwaha, 27(1), 3-14. https:/ /doi.org/10.32477/jkb.v27i1.318 